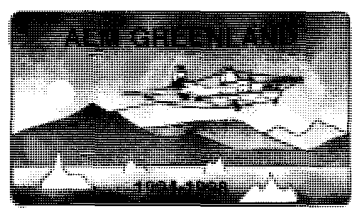

\title{
A new airborne electromagnetic and magnetic survey of Inglefield Land, North-West Greenland: Project AEM Greenland 1994-1998
}

\author{
Robert W. Stemp and Leif Thorning
}

Late in 1993 the Greenland Home Rule Government decided to finance a five-year programme of airborne geophysical surveying over selected regions of Greenland, project AEM GREENLAND 1994-1998, with approximately five million kroner per year. The primary objective is to stimulate mining exploration activity in Greenland over the short term. The secondary objective is to provide data which will have a lasting effect in the interpretation of the geology in selected parts of Greenland. The Geological Survey of Greenland (GGU) manages the project, carries out interpretations of the data, and will maintain the acquired data in digital databases as a service to the public and mining companies (MINEX, 1994a, b).

The first survey undertaken in this project was a combined electromagnetic and magnetic airborne survey over Inglefield Land in North-West Greenland in 1994, flown by Geoterrex Ltd of Ottawa, Canada, under a contract with GGU after a public round of tenders.

The survey acquired 17341.5 line kilometres of high quality data. Except for some areas near the coast covered by sedimentary rocks, nearly all of Inglefield Land was surveyed in detail, with flight lines extending from the Inland Ice to the sea (Fig. 1).

This paper presents a brief and general report on the field work; detailed information can be found in the Geoterrex field report, and in an open file report (Stemp \& Thorning, 1995) published simultaneously with the release of the digital data from the survey on 1 February 1995.

The funding of the next survey in project AEM Greenland 1994-1998 has now been confirmed by the Greenland parliament; the region between Nuuk and Maniitsoq, central West Greenland has been chosen as the survey area for 1995.

\section{Geology}

A summary of the geology of Inglefield Land is given by Dawes (1988). Most of the information is based on coastline mapping by boat (particularly in the south-west) and photogeological interpretation.

The area is dominated by an Early Proterozoic (and possibly Archaean; Kalsbeek, 1994) crystalline basement, which has been provisionally subdivided into three main units: (i) the Etah group of metasedimentary supracrustal rocks, (ii) Etah meta-igneous complex, and (iii) variable gneisses. In the northern coastal regions of Inglefield Land the basement is overlain by a succession of sedimentary strata of Proterozoic to Cambrian age. Large areas are covered by glacial outwash.

In reality, the geology of Inglefield Land is poorly known, in particular the crystalline basement. Although no economic mineralisation has been reported from the area, previous commercial exploration has been limited to a surficial check of some large, bright yellow gossans, and cannot be considered conclusive. The gossans are very common in the region, and most of them have still not been examined. The presence of massive sulphide mineralisations of economic interest in the Proterozoic basement cannot be ruled out. At the time of the start of project AEM Greenland 1994 no licenses for mineral exploration were active in the area.

The existing topographic maps of Inglefield Land were not adequate for the detailed geophysical surveying planned. Project AEM Greenland 1994-1998 therefore funded the production of new topographic maps at scale 1:100 000 prepared in GGU's photogrammetric laboratory from 1:150 000 aerial photographs before the field operation commenced, together with a photogeological study based on the same material (Bengaard, 1995).

\section{Equipment and survey parameters}

The U.S. Air Force Base in Thule (TAB) approximately 200 kilometres south of Inglefield Land was used as a base for the field operations. The airborne programme was carried out between 1 July and 29 August, 1994, using a Geoterrex CASA aircraft equipped with the GEOTEM transient electromagnetic system. This consists of a horizontal transmitter loop mounted around the nose, tail and wingtips of the aircraft, and a vertical receiver coil mounted in a sensor (bird) towed below and behind the aircraft (Fig. 2). The aircraft also carries a cesium vapour, high sensitivity magnetometer with a sensor in a second bird. Monitoring of all aspects of the field work, data evaluation, and preliminary interpretation was carried out by GGU in Thule during the field operations.

Primary navigation and flight path recovery was based 

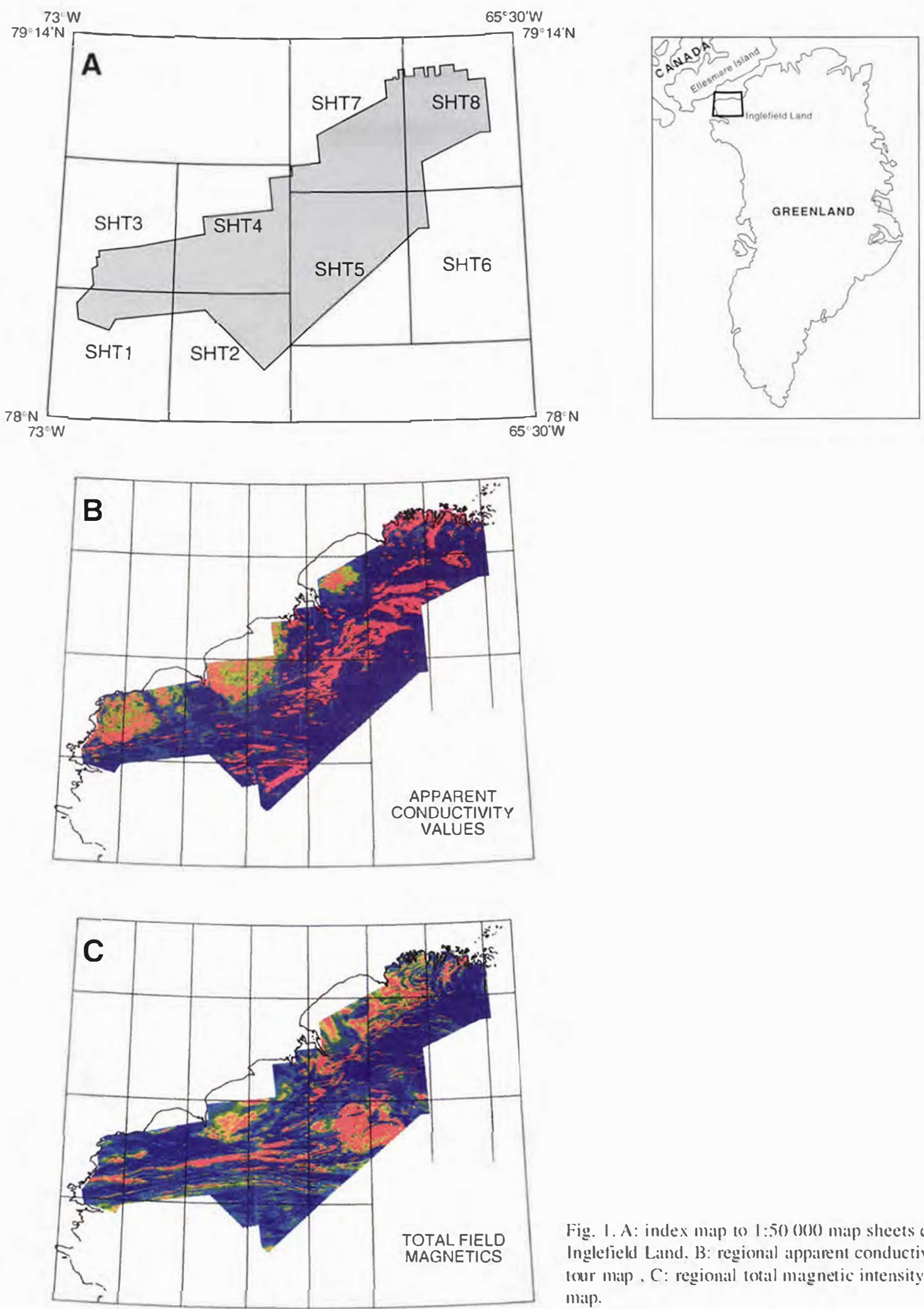

Fig. I. A: index map to $1: 50000($ map sheets covering Inglefield Land. B: regional apparent conductivity contour map. C: regional total magnetic intensity contour malp. 
on the use of Global Positioning System (GPS) in differential mode, but the aircraft was also equipped with a Doppler airborne navigation system, a colour video camera for flightpath recording and the usual suite of ancillary equipment for geophysical surveying. Ground monitors placed at TAB consisted of a GPS receiver for post-flight differential processing of the flight path and a cesium vapour magnetometer to measure the magnetic diurnal variation.

Flight lines were flown in a north-south direction at $400 \mathrm{~m}$ intervals. Tie lines were spaced at $4000 \mathrm{~m}$ intervals, at right angles to the main flight line direction. The mean terrain clearance of the aircraft was $120 \mathrm{~m}$ with the magnetic sensor bird at $73 \mathrm{~m}$ and the EM receiver bird at $64 \mathrm{~m}$ approximate height above terrain.

Twelve channels of electromagnetic information were recorded during the transmitter off-time and one channel during the transmitter on-time. The EM sampling interval was six times per second yielding a sampling interval along the ground of approximately $10 \mathrm{~m}$. The high sensitivity magnetic data were recorded with a resolution of $0.01 \mathrm{nT}$ at a sample rate of ten times per second. The final flight path positioning is accurate to $25 \mathrm{~m}$ or better. The highest quality was required for all parameters measured.

Further details on the field work, instrumentation and methods can be found in Geoterrex (1994), and in the GGU open file report (Stemp \& Thorning, 1995).

\section{Compilation products}

All data were inspected in the field as analog profiles of most measured parameters produced in flight. Corrected versions of these were later delivered to GGU as multiparameter profiles in digital form on CD-ROM with appropriate software to view the data on a PC. The final data were also delivered as line and grid archive data on CD-ROM.

The data were compiled on the new topographic maps at a primary scale of 1:50 000. Additional composite maps at scale 1:250 000 and 1:1000 000 have also been produced by Geoterrex. The following compilation products were produced in preliminary form in the field, and subsequently prepared in a more final form at the Geoterrex Ottawa office for final delivery:

- GEOTEM anomaly maps with flight lines, picked anomalies, and topographic information

- GEOTEM decay constant (tau) contour maps

- GEOTEM channel 2 contour maps

- Apparent conductivity contour maps calculated using the full EM wave form

- Total field magnetic anomaly maps

- Vertical gradient of the total field anomaly maps

The compilations reproduced in Fig. 1 are based on
1:1 000000 plots of the data and, it must be stressed, in no way do justice to the amount of detail available in the original 1:50 000 scale maps or in the digital data.

\section{Survey results}

The Inglefield Land AEM and aeromagnetic survey must be considered very successful. The electromagnetic and magnetic data obtained through this low altitude, detailed survey provide an enormous amount of information and will be a key source for any mineral exploration or geological mapping for many years to come. At the time of writing, even the preliminary interpretation of the geophysical data has not been concluded. Results are reported elsewhere (Stemp \& Thorning, 1995). Here, a brief overview is presented of some general, but significant results already obtained.

An unusually large number of bedrock EM anomalies (approximately 4600) were detected by the electromagnetic survey. They can initially be divided into two main categories:

(1) Anomalies grouping into long, multiple formational conductive zones conformable with regional magnetic (i.e. geological) trends.

(2) Anomalies typical of short, isolated bedrock conductors, sometimes also associated with localised magnetic features.

The first type of formational bedrock conductors may be due to either massive sulphide or graphite, or to a combination of the two. Previous prospecting of a few of the gossans by a mining company in Inglefield Land has revealed massive pyrrhotite or pyrite zones of varying widths and some graphite. The airborne survey has now established that the large gossan zones are directly associated with the long, multiple conductor horizons. Because of the large number of anomalies, it will be a major effort to prospect for economic mineralisations within the widespread horizons revealed by the electromagnetic data.

Bodies associated with the second type of anomaly normally provide good prospects for economic, massive sulphide mineralisations. They are also easier to evaluate on the ground, and it is interesting that this group of anomalies has probably never been visited or studied in Inglefield Land. Thus, the AEM survey has revealed a new group of possible prospects.

In Inglefield Land, the almost total absence of any surficial conductivity, i.e. conductive overburden, has greatly enhanced the value of the EM data for mapping purposes (Annan et al., in press). The apparent conductivity map produced (Fig. 1), clearly differentiates between the unmineralised, highly resistive crystalline basement rocks, the less resistive cover rocks, certain weakly conducting fault and shear zones, and the highly conducting massive 


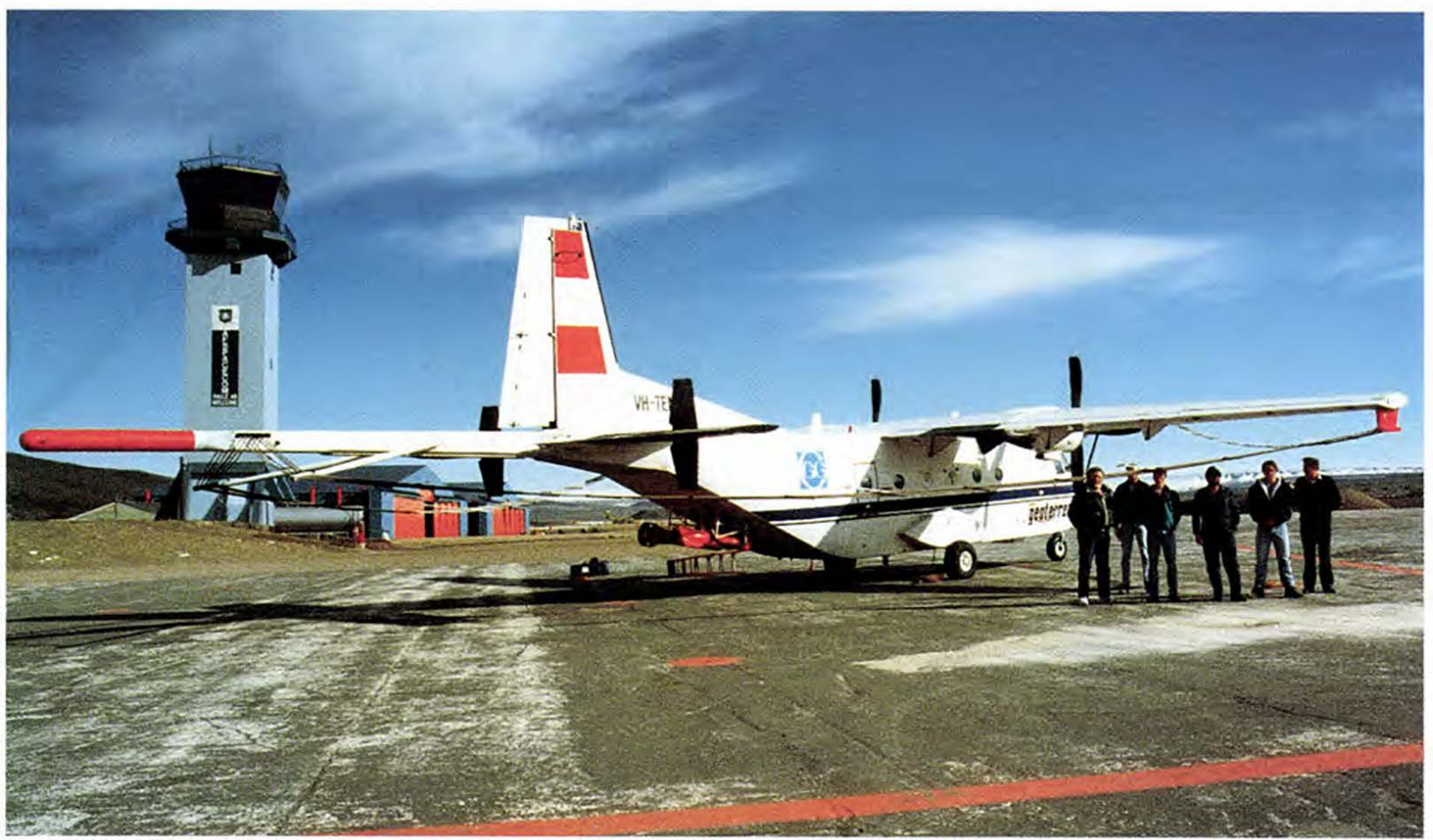

Fig. 2. The Geoterrex aircraft and crew at Thule Air Force Base. August 1994.

sulphide or graphite horizons of the supracrustal belts.

The primary role of the detailed aeromagnetic data also acquired in this project is to help in the geological mapping. both regionally and locally, particularly in the regions where glacial outwash material covers the basement leaving only few bedrock exposures to be studied directly. The supracrustal belts are easily traced across the map area, some of them for tens of kilometres, and individual units within the belt can be identified by their varying magnetic intensities. The magnetic map also accurately portrays strike directions, major fold structures, igneous units, and linear dykes and fault zones (Fig. 1).

The magnetic data can also be used in a more direct prospecting role. for example:

- to help analyse EM conductors with the view to possible source and economic potential:

- to locate ultrabasic units which may be prospected for nickel or platinum group metals:

- to map fault and shear zones of possible interest in e.g. gold exploration:

- to locate and further analyse circularfcatures which may be of interest in kimberlite exploration; many such features can be seen in the video recordings of the flight path. some of them have a geophysical expression. and the photogeological study by Bengaard (1995) has confirmed their existence in large numbers.

\section{Conclusions}

The AEM and aeromannetic survey of Inglefield Land carried out in 1994 by Geoterrex Lid has proved a good start for the AEM GREENLAND 1994-1998 project. As expected, the Inglefield Land area has been shown to have a major economic potential with many possible targets for further exploration, enhancing the status of Inglefield Land as a prime mineral exploration area. Thus, although the interpretation is still ongoing, it is already now clear that the primary objective of the project. to stimulate further exploration activity, has been reached. A large number of promising, individual geophysical targets for follow-up field work are defined in Stemp \& Thorning (1995). The sources of the many gossans in the area have been shown to be almost entirely formational EM conductors, some of which may have an economic potential. Other. previously unknown single. isolated conductors have also been identified. The determination of the exact character of the sources will be a subject of further GGU field work in the area during 1995.

The detailed study of the new geophysical data set has barely begun, but there is no doubt that the secondary objective of the project, 1 o provide data with a lasting effect for geological research, will also be realised. Further analysis and study of the new geophysical data by GGU will take advantage of other types of data at both local and regional scales e.g. photogeology, gravity, and Landsat 
satellite imagery. Major progress towards a geological map of the area will take place. The digital data, which will play a major role for any kind of exploration taking place in Inglefield Land, are available at low cost for the mining industry.

Acknowledgements. The Geoterrex field crew, office compilation staff, and management carried out their various tasks connected with AEM Greenland 1994-1998 with dedication and skill. Erik Thomsen and his staff at the Danish Liaison Office in Thule are thanked for providing local support. Thanks are due also to the authorities and personnel of USAF/TAB for their co-operation and help. Fruitful cooperation with Erik Andersen, representing the Greenland Home Rule Government, and with the Mineral Resources Administration, Danish Ministry of Environment and Energy is gratefully acknowledged.

\section{References}

Annan, A. P., Smith, R. S., Lemieux, J., O’Connell, M. D. \& Pedersen, R. N. in press: Resistive-limit time-domain AEM apparent conductivity. Geophysics.
Bengaard, H.J. 1995: Photogeological interpretation of Inglefield Land, North-West Greenland. Open File Ser. Grønlands geol. Unders. 95/4, $21 \mathrm{pp}$.

Dawes, P. R. 1988: Etah meta-igneous complex and the Wulff structure: Proterozoic magmatism and deformation in Inglefield Land, North-West Greenland. Rapp. Grønlands geol. Unders. 139, 24 pp.

Geoterrex 1994: Logistics \& processing report of an airborne GEOTEM electromagnetic and magnetic survey over Inglefield Land, Greenland for the Geological Survey of Greenland. Unpublished report, Geoterrex, Canada.

Kalsbeek, F. 1994: Archaean and early Proterozoic basement provinces in Greenland. Rapp. Grønlands geol. Unders. 160, $37-40$.

MINEX, 1994a: Five-year airborne geophysics project. Greenland MINEX news 4, 4 only.

MINEX, 1994b: Project AEM Greenland 1994-98. Greenland MINEX news 5, 3-4.

Stemp, R. W. \& Thorning, L. 1995: Airborne electromagnetic and magnetic survey of Inglefield Land North-West Greenland. Results from project AEM Greenland 1994. Open File Ser. Grønlands geol. Unders. 95/1, 45 pp.

R. W. S. \& L. T., Geological Survey of Denmark and Greenland, Copenhagen 